\title{
КРИМІНОЛОГІЧНИЙ АНАЛІЗ ТА НАУКОВЕ ОБҐРУНТУВАННЯ СУЧАСНИХ МЕТОДІВ ІНДИВІДУАЛЬНОЇ ПРОФІЛАКТИКИ КОРИСЛИВИХ ЗЛОЧИНІВ НЕПОВНОЛІТНІХ
}

Гумін О. М., Гуцул Р. Р.

Розглянуто та проаналізовано особливості індивідуальної профілактики корисливих злочинів неповнолітніх і методику їі реалізації. Доведено доцільність розмежовування методів вивчення особистості неповнолітнього правопорушника з метою подальшої профілактики правопорушень, а також безпосередньо методів індивідуальної профілактики, з'ясована сутність відповідних методів, наведено рекомендації щодо їх продуктивної реалізаціі. Запропоновано методи індивідуальної профілактики корисливих злочинів неповнолітніх, які використовують психологи та педагоги як засоби виховного впливу на неповнолітніх правопорушників.

Ключові слова: профілактика, правопорушення, корисливі злочини, неповнолітні.

Рассмотрены и проанализированы особенности индивидуальной профилактики корыстных преступлений несовершеннолетних и методика ее реализации. Доказана челесообразность разграничения методов изучения личности несовершеннолетнего правонарушителя с целью дальнейшей профилактики правонарушений и непосредственно методов индивидуальной профилактики, выяснена сущность соответствующих методов, приведены рекомендации по их продуктивной реализации. Предложены методы индивидуальной профилактики корыстных преступлений несовершеннолетних, которые используют психологи и педагоги в качестве средств воспитательного воздействия на несовершеннолетних правонарушителей.

Ключевые слова: профилактика, правонарушения, корыстные преступления, несовершеннолетние.

Humin O. M., Hutsyl R. R. Criminological analysis and scientific justification of modern methods of individual prevention of judicial crimes

Peculiarities of individual prevention of mercenary juvenile crimes and methods of its implementation are considered and analyzed. The expediency of distinguishing the methods of studying the personality of a juvenile offender for further prevention of offenses, as well as directly the methods of individual prevention, clarifies the essence of the relevant methods, provides recommendations for their productive implementation. Methods of individual prevention of mercenary juvenile crimes, which are used by psychologists and teachers as a means of educational influence on juvenile offenders, are proposed. The existing preventive activity of mercenary crimes of juveniles is based on extensive forms and methods of work. Preventive and educational methods are focused mainly on social and pedagogical assistance, in order to avoid, first of all, measures of administrative-legal or criminal influence. There is no differentiated approach to working with minors, who are difficult to raise, whose deviant behavior worries teachers, parents, the public. However, whether the state policy on minors is really defined in full and whether it is sufficiently provided with effective methods of prevention, these issues need to be studied in

(c) Гумін О. М., Гуцул Р. Р., 2020 detail. In order to improve the methods and forms of prevention of deviant behavior of minors, it is necessary to diversify the practical methods of legal influence and combine them with the socio-pedagogical impact on adolescents in the activities of probation bodies. It should be noted that the legal impact of individual prevention will be effective only when legal norms will not only exist (be adopted, published, etc.), but will operate in everyday life, in other words, actually to put in order, to regulate, to guard public relations in this sphere.

Key words: prevention, offenses, mercenary crimes, minors.

Постановка проблеми та іï актуальність. Процеси трансформації українського суспільства зумовили зміни багатьох сфер життя, що призвело до суттєвих хиб у молодіжному середовищі: діти і підлітки дорослішають під час руйнації ціннісних орієнтирів та моральних норм, майнової поляризації та розшарування суспільства. Існуюча профілактична діяльність корисливих злочинів неповнолітніх побудована на екстенсивних формах та методах роботи. Профілактично-виховні методи зорієнтовані переважно на соціально-педагогічну допомогу, щоб уникнути передусім заходів адміністративно-правового чи кримінального впливу. Відсутній диференційований підхід до роботи з неповнолітніми, які складно піддаються вихованню, чия девіантна поведінка турбує вчителів, батьків, громадськість. Детального вивчення потребують питання: чи дійсно державна політика стосовно неповнолітніх визначена повним обсягом, чи належно забезпечена дієвими методами профілактики.

Аналіз останніх досліджень і публікацій. Феномен девіантної поведінки неповнолітніх, що вчиняють корисливі злочини, а саме крадіжку, грабіж, розбій вивчають такі сучасні вітчизняні та російські дослідники, як: В. Білоус, А. Дзюба, І. Козубовська, Н. Кулакова, В. Оржеховська, О. Пилипенко, І. Трубавіна, Т. Федорченко (Україна); М. Заостровцева, О. Єгоров, В. Менделєвич, Н. Платонова (Росія). Саме вони визначають індивідуальну профілактику як складну об'єктивно зумовлену систему керованої діяльності, що закономірно складається на конкретному історичному етапі суспільного життя та забезпечує науково-теоретичне розроблення i практичну реалізацію заходів для запобігання девіантній поведінці неповнолітніх.

Мета статті - проаналізувати сучасні методи індивідуальної профілактики корисливих злочинів неповнолітніх, науково обґрунтувати девіантні вияви в поведінці підлітків. Визначити напрями, за якими потрібно працювати суб'єктам індивідуальної профілактики корисливих злочинів неповнолітніх для вдосконалення методів профілактики девіантної поведінки неповнолітніх, що вчиняють корисливі злочини. 
Виклад основного матеріалу. Профілактика правопорушень корисливих злочинів неповнолітніх - проблема державна, оскільки передбачає перехід від тоталітаризму і покарання до демократії та відповідальності. На профілактику правопорушень спрямовано окрему програму Кабінету Міністрів України, розробляються закони, система заходів, виділяється фінансування.

Проблема полягає в тому, що вихована людина - та, яка діє за правовими і моральними нормами незалежно від того, контролює ї̈ вчинки хтось або ні. Це педагогічний аспект профілактики - як зробити так, щоб неповнолітній сам хотів та прагнув дотримуватись моральних і правових норм. Нині існує безліч методів, програм профілактики правопорушень для неповнолітніх у різних установах, $є$ навіть проєкт закону України «Про профілактику правопорушень», але потрібні їх систематизація й узагальнення, розроблення рекомендацій щодо їх використання, узгоджена система роботи на державному, регіональному та місцевому рівнях [1, с. 1].

Як відомо, девіантна поведінка - це система вчинків або окремих проступків, які суперечать прийнятим у суспільстві нормам і виявляються в незбалансованості психічних процесів, неадаптивності, порушенні процесу самоактуалізації та відхиленнях від морального й естетичного контролю над особистісною поведінкою [2].

Передумовою профілактики девіантної поведінки підлітків $\epsilon$ також діяльність державних інституцій, зокрема й органів кримінально-виконавчих інспекцій, а також специфіка організації цієї профілактики: окреслення законодавчим полем кола неповнолітніх осіб (діти віком від 14 до 18 років); ужиття заходів та використання комплексних чи поодиноких методів, спрямованих на профілактику девіантної поведінки підлітків; диференціація підрозділів, які здійснюють профілактику паралельно з виконанням основних службових обов'язків, підрозділів, спеціально уповноважених здійснювати профілактичну роботу серед підлітків, засуджених до покарань, які не пов'язані з позбавленням волі, та спеціальних установ для дітей, які вчинили злочини [3, с. 141].

Індивідуальна профілактична робота проводиться з особами, що $є$ потенційними та реальними жертвами злочинів унаслідок своєї поведінки, способу життя, фізичних або психічних особливостей, соціально-рольових цінностей. 3 метою всебічного вивчення особистості можуть застосовуватися такі методи, як ознайомлення з різними документами (зокрема й узагальнення незалежних характеристик); аналіз учинків особи, що профілактується, бесіди із громадянами, що добре знають таку особу, вивчення ії оточення тощо. У процесі вивчення особи здійснюється прогнозування їі індивідуальної поведінки. Інформація про минуле та сьогодення особи, соціальні зв'язки, найближче оточення $\epsilon$ основою для прогнозу її майбутньої поведінки, щоб визначити найбільш раціональні шляхи профілактичної роботи з особами, що перебувають на профілактичному обліку, забезпечити вибір необхідних тактичних методів і прийомів [4, с. 213; 5, с. 320].

Проведення індивідуальної профілактики корисливих злочинів неповнолітніх пов'язане з подоланням серйозних труднощів, чимало з яких породжено особливостями сучасної ситуації. Основні із цих особливостей такі [4, с. 250]: система недержавних суб'єктів індивідуальної профілактики (добровільні народні дружини, товариські суди, будинкові комітети тощо), що діяла раніше, практично розпалася;

через збільшення числа безробітних стрімко зросла кількість маріінальних елементів (неповнолітні перетворюються на волоцюг, жебраків тощо), які майже не піддаються індивідуально-профілактичному впливу та поповнюють лави злочинців;

відсутність упевненості у завтрашньому дні, у перспективі соціального благополуччя - це ускладнює відносини у багатьох родинах, спричиняє побутові конфлікти, негативно впливає на виховання неповнолітніх, часом перекреслює всі зусилля індивідуально-профілактичного впливу;

ліквідація одних (лікарняно-трудові профілакторії) і спроби реорганізації інших (спецприйомники, приймальники-розподільники для дітей) місць ізоляції марґінальних елементів і правопорушників різко знизили можливості застосування примусовий заходів до осіб, на яких переконання не діють.

Усе це змушує шукати нові методи індивідуально-профілактичного впливу, уживати заходів щодо відновлення у зміненому вигляді системи суб'єктів і заходів індивідуальної профілактики.

Учені Ю. Заросинський, І. Козубовська, Д. Нелюбіна, В. Оржеховська у своїх працях наголошують на тому, що найголовнішою характеристикою гуманістично-діяльнісного підходу має бути створення умов для розвитку духовних і фізичних сил підлітка, його захист. Зокрема, забезпечення основних прав і основоположних свобод дитини. Цей підхід передбачає усвідомлення суб'єктом своїх прав і обов'язків, необхідності втілювати їх у своєму житті. Він має спрямовуватися не лише на неповнолітніх, а й на батьків, учителів, представників дитячих і молодіжних організацій, благодійних фондів, представників органів пробації, які $\epsilon$ учасниками процесу профілактики. Застосування цього підходу потребує постійного вдосконалення змісту, форм і методів профілактики девіантної поведінки підлітків підрозділами органів кримінально-виконавчих інспекцій $[6 ; 7$, с. 9; 8, с. 254; 9; 10$]$.

За період 2013-2017 рр. кількість злочинів, учинених неповнолітніми, продовжувала скорочуватись, до того ж їх рівень знижувався щорічно. у 2013 р. було зареєстровано 8781 злочинів (питома вага у структурі злочинності становить 1,5\%), у 2014 р. - 7467 (питома вага $1,4 \%)$, у 2015 р. - $6647(1,3 \%)$, у 2016 р. - $5230(0,9 \%)$, у 2017 р. - 5608 (1,1\%) [11]. Аналіз стану злочинності неповнолітніх за період із 2013 р. по 2017 р., зокрема його рівня і структури, свідчить про досить помітне, порівняно з попередніми роками, зниження рівня злочинів, учинених неповнолітніми, i водночас майже незмінні показники структури злочинності неповнолітніх. Проте таке зменшення рівня злочинності зумовлене не лише його фактичним зменшенням, а поступовим скороченням кількості населення, виїздом молоді з метою працевлаштування за кордон, а також відсутністю офіційної реєстрації злочинів на території нашої держави. Варто зазначити, злочини даної категорії характеризуються високим рівнем латентності, а тому офіційна статистика не відображає реального їі стану. Зокрема, за результатами наукового дослідження корисливої злочинності щодо неповнолітніх, латентна 
частина грабежів та розбоїв, учинюваних щодо неповнолітніх, становить до 70\%, наприклад вимагань - до 90\%. Спираючись на це, можемо уявити реальну кількість учинюваних корисливих злочинів щодо неповнолітніх, яка $€$ досить невтішною [12].

Безпосереднє здійснення індивідуальної профілактики - досить тривалий і систематичний процес, що пов'язаний із впливом на особу, під час якого необхідно комплексно застосовувати весь арсенал методів, усі засоби та заходи впливу. Автономна група способів, підходів і прийомів кримінологічного впливу, що дозволяють упорядкувати, направити й ефективно організувати виконання профілактичних функцій і операцій. Методи даної групи варто розглядати як поняття, яке розкриває образ дій суб'єкта під час здійснення діяльності на даному профілактичному рівні.

Сутність методів даної групи визначається характером впливу суб'єкта на об'єкт, який зумовлений діалектичною взаємодією цілей впливу, специфікою діяльності суб'єкта і засобів, що використовуються для зміни об'єкта. У практичній діяльності використовуються такі методи індивідуально-профілактичного впливу, як: переконання, надання допомоги, примус, реґламентації, рекомендації та метод еталонного зразка.

Метод переконання - це комплекс виховних, роз'яснювальних заходів, що здійснюються з метою зміни антигромадської спрямованості осіб, що профілактуються, і закріплення їхньої позитивної соціальної орієнтації. Він застосовується в період перебування осіб на профілактичному обліку для подолання або нейтралізації основних антигромадських орієнтацій, що можуть призвести до вчинення злочинів. Основними формами реалізації методу переконання $\epsilon$ індивідуальні або колективні бесіди, обговорення поведінки особи, встановлення над нею індивідуального або колективного шефства, спільна участь вихователя й особи, що перевиховується, у суспільно корисній діяльності тощо. У процесі застосування методу переконання необхідно використовувати різноманітні психологічні та педагогічні прийоми впливу на розум, почуття і волю людини. Основною організаційно-тактичною формою виховного впливу на особу, що профілактується, $\epsilon$ бесіда. Використовуються бесіди трьох видів: попередня (або ознайомлювальна), профілактична і виховна. Попередня бесіда проводиться в індивідуальному порядку під час постановки особи на профілактичний облік. Профілактичну бесіду проводять за наявності фактів антигромадської поведінки особи, що перебуває на профілактичному обліку. Виховна бесіда за своїм змістом та способом впливу нагадує профілактичну, але виховні бесіди проводяться здебільшого в неофіційній обстановці, частіше - представниками громадськості за місцем проживання, навчання або роботи особи, що профілактується [5, с. 326].

Метод надання допомоги зазвичай найбільш ефективний у профілактичній діяльності неповнолітніх. Він передбачає: допомогу у працевлаштуванні, поліпшенні побутових умов, організації дозвілля, встановленні соціально корисних контактів, плануванні грошових видатків, виборі життєвих цілей тощо. Заходи надання допомоги у працевлаштуванні та створенні належних побутових умов, особливо особам, звільненим із місць позбавлення волі після відбуття покарання, регламентовані в низці нормативних актів.
У зв'язку із цим для надання допомоги особам, що профілактуються, необхідно використовувати можливості меценатів, різних фондів, служби соціального захисту населення, центрів соціальної реабілітації й інших подібних структур [5, с. 331].

Метод примусу $\epsilon$ одним з основних методів індивідуально-профілактичної діяльності не тільки корисливих злочинів неповнолітніх, а й усіх злочинів загалом. Він реалізується шляхом застосування різних за своєю юридичною природою, змістом і спрямованістю заходів впливу, які реґламентуються нормами відповідних галузей права: цивільного, сімейного, адміністративного тощо.

Регламентація як метод профілактики корисливих злочинів неповнолітніх полягає в розробці і введенні в дію індивідуального правозастосовного акта, який приписує здійснення певного набору дій особою, що потрапила в орбіту профілактичного впливу. Цей метод характеризується строгою обов'язковістю виконання приписаних дій. Однією з форм регламентації натепер $\epsilon$ адміністративний нагляд. Метод рекомендації $\epsilon$ не таким категоричним, як чотири попередніх, оскільки не встановлює положень, які мають обов'язковий характер. Рекомендація має форму методичної й інформаційної допомоги, реалізується консультуванням. Зміст даного методу є різноманітним: пояснення значущості соціально схвалюваної поведінки, роз'яснення суспільної небезпеки і протиправності окремих форм поведінки неповнолітнього, попередження з боку суб'єкта індивідуальної профілактики про неприпустимість протиправних дій, роз'яснення можливих шляхів вирішення проблем тощо. Цей метод передбачає, що суб'єкт на основі одержаної корисної інформації сам вирішує скористатися найактуальнішиими рекомендаціями [13, с. 226].

Метод еталонного зразка $\epsilon$ не таким широко використовуваним, але передбачає вжиття заходів, спрямованих на перенесення позитивних характеристик із найефективнішого об'єкта (еталон) на менш ефективний. Проте варто застерегти від бездумного копіювання еталона без урахування відмінностей середовища функціонування і внутрішніх відмінностей об'єктів, оскільки в такому разі можливий зворотний ефект. Не випадково мають рівне право на існування два на перший погляд однакові поняття - передовий досвід і позитивний. Перший ефективно застосовують до всієї групи об'єктів, другий - лише до частини. Уважаємо за необхідне окрему увагу приділити діяльності суб'єктів, що мають можливість розробити та застосовувати заходи як індивідуальної, так і віктимологічної профілактики щодо неповнолітніх. На нашу думку, їх можна поділити на дві групи: спеціалізовані та неспеціалізовані. Так, до першої групи належать ті суб'єкти, які діють у межах наданої їм компетенції, а саме: правоохоронні органи, органи освіти, охорони здоров'я, соціального захисту і зайнятості населення, а також юридичні організації підприємств, організацій тощо. До другої групи суб'єкти, які беруть участь у профілактичній роботі за власною ініціативою або ж за дорученням державних органів, а саме: комерційні і некомерційні організації, підприємства й установи, політичні партії та громадські установи, об'єднання та молодіжні формування, профспілки, заклади фізичного виховання та спорту, охоронні служби, засоби масової інформації, різного 
роду асоціації та співтовариства, благодійні структури та релігійні організації тощо. Окрему категорію суб' $є$ ктів профілактичної роботи з неповнолітніми становить сім'я, у якій вони проживають [13, с. 231].

Індивідуальна профілактика - складний вид діяльності, оскільки вона завжди пов'язана з конкретною людиною, іiі індивідуальною неповторністю, зі специфікою її життєвого досвіду. Тому, оцінюючи ії результативність, необхідно враховувати, що, по-перше, ефективність профілактики злочинів досягається застосуванням не одного окремо взятого заходу, а цілого їх комплексу; по-друге, результат профілактичної роботи, за тих самих форм і методів, суттєво змінюється залежно від ступеня криміногенності кожного із трьох основних детермінантів злочинної поведінки - особи, мікросередовища та конкретної ситуації; по-третє, інтенсивність профілактичних заходів перебуває у прямій залежності від ступеня вияву названих криміногенних чинників.

Наприклад, якщо одні методи є більш гуманними, оскільки спрямовані на переконання тієї чи іншої особи в недопущенні протиправної поведінки, то інші пов'язані із застосуванням тих чи інших заходів примусу до осіб, які допускають відхилення в поведінці. Безумовно, названі методи мають застосовуватися з урахуванням соціальної запущеності особи. 3 допомогою цих методів суб'єкти профілактики правопорушень, залежно від ïх виду, застосовують різні форми, під якими розуміється науково обґрунтована система найбільш доцільних і правомірних заходів індивідуальної профілактики злочинів неповнолітніх [7, с. 14].

Висновки. Щоб удосконалювати методи та форми профілактики девіантної поведінки неповнолітніх, потрібно урізноманітнити практичні прийоми правового впливу та поєднати їх із соціально-педагогічним впливом на підлітків у діяльності органів пробації. Варто зазначити, що правовий вплив індивідуальної профілактики буде ефективним лише тоді, коли правові норми будуть не лише існувати (ухвалені, опубліковані тощо), а діятимуть у повсякденному житті, тобто фактично упорядковувати, реґламентувати, охороняти суспільні відносини в цій сфері. Для вдосконалення форм і методів індивідуальної профілактики корисливих злочинів неповнолітніх у процесі діяльності потрібно працювати у трьох напрямах: працювати з кадрами, підвищувати їхній кваліфікаційний рівень відповідно до сучасних науково обґрунтованих підходів до проблеми індивідуальної профілактики девіантної поведінки неповнолітніх; розробляти та запроваджувати в дію нові форми та методи роботи із профілактики девіантної поведінки
Протидія злочинності: проблеми практики та науково-методичне забезпечення

підлітків в органах кримінально-виконавчої інспекції; здійснювати моніторинг індивідуальної профілактики девіантної поведінки неповнолітніх.

\section{Література}

1. Трубавіна І. Аналіз існуючих у практиці підходів до профілактики правопорушень у дітей в Україні : педагогічний аспект. URL: http: / /www.nbuv.gov.ua/e-journals/ Vnadps/2010_3/10timupa.pdf (дата звернення: 14.05.2020).

2. Невский И. Вопросы изучения детей с отклонениями в поведении : сборник статей. Москва, 1968. 180 с.

3. Микитенко М. Сучасний стан профілактики девіантної поведінки підлітків органами кримінально-виконавчої інспекції. Науковий вісник. 2014. № 1. С. 136-142

4. Кримінально-виконавче право України : підручник / О. Джужа та ін. ; за заг. ред. О. Джужі. Київ : Атіка, 2010. 752 c.

5. Профілактика злочинів : підручник / О. Джужа та ін. ; за заг. ред. О. Джужі. Київ : Атіка, 2011. 720 с.

6. Оржеховська В. Профілактика правопорушень серед неповнолітніх : навчально-методичний посібник. Київ : ВiAH, 1996. 351 с.

7. Нелюбіна Д. Профілактика правопорушень серед неповнолітніх. Магістеріум. Соціальна робота в охороні здоров'я. 2006. № 25. С. 9-14.

8. Заросинський Ю. Характеристика осіб неповнолітнього віку, що вчиняють злочини. Економіка і право. Серія 18 «Право». 2015. № 27. С. 254-259.

9. Оржеховська В. Профілактика девіантної поведінки неповнолітніх. Черкаси, 2008. 376 с.

10. Козубовська І. Рання профілактика протиправної поведінки неповнолітніх: психолого-педагогічні аспекти : дис. ... докт. пед. наук: 13.00.01. Ужгород, 1996. 422 с.

11. Про зареєстровані кримінальні правопорушення та результати їх досудового розслідування : статистична інформація. URL: http://www.gp.gov.ua/ua/stst2011. html?dir_id=111482\&libid=100820\&c=edit\&_c=fo.

12. Єдиний звіт про осіб, які вчинили кримінальні правопорушення за 2016/2017 pp. URL: http: / /www.gp.gov.ua/ ua/stst2011.html?dir_id=111482\&libid=100820\&c=edit\&_ $\mathrm{c}=$ fo.

13. Вісник Кримінологічної асоціації України : збірник наукових праць. Харків : ХНУВС, 2018. № 2 (19). 262 с.

Гумін О. М., доктор юридичних наук, завідувач кафедри кримінального права і процесу Національного університету «Львівська політехніка»

Гуцул P. P., аспірантка IV курсу кафедри кримінального права i процесу

Національного університету «Львівська політехніка» 